\title{
Hubungan antara Estimasi Kapasitas Cranium dengan Prestasi Akademik pada Mahasiswa
}

\author{
Correlation between Estimation of Cranial Capacity With Academic Achievement of Students \\ Rochman Basuki $^{1 *}$, Sigit Moerjono ${ }^{1}$, Tanti Fatikha Sari ${ }^{2}$ \\ ${ }^{1}$ Bagian Ilmu Anatomi, Fakultas Kedokteran Universitas Muhammadiyah Semarang, Indoensia \\ ${ }^{2}$ Mahasiswa Fakultas Kedokteran Universitas Muhammadiyah Semarang, Indonesia \\ *Penulis Korespondensi: Rochman Basuki. Email: rochmanbasuki79@unimus.ac.id
}

\begin{abstract}
ABSTRAK
Latar Belakang: Banyak orang percaya bahwa semakin besar ukuran otak seseorang maka semakin tinggi pula tingkat kecerdasannya. Pertumbuhan otak manusia berjalan seiring dengan pertumbuhan cranium. Prestasi akademik merupakan salah satu parameter yang dapat menjabarkan inteligensi seorang mahasiswa. Tujuan penelitian ini untuk mengetahui hubungan antara estimasi kapasitas cranium dengan prestasi akademik pada mahasiswa.

Metode: Penelitian ini merupakan penelitian observasional analitik dengan pendekatan cross sectional dengan metode total sampling mahasiswa semester 5 angkatan 2015 Fakultas Kedokteran Universitas Muhammadiyah Semarang (n=66). Estimasi kapasitas cranium sebagai variabel bebas dan prestasi akademik sebagai variabel terikat. Analisis bivariat menggunakan korelasi Spearman.

Hasil: Nilai mean estimasi kapasitas cranium 1570,40 cc dan nilai mean indeks prestasi akademik 2,80. Hasil korelasi Spearman didapatkan nilai signifikansi $(\mathrm{p}=0,031)$ menunjukkan bahwa penelitian ini menunjukkan hubungan antara estimasi kapasitas cranium dengan prestasi akademik.
\end{abstract}

Kesimpulan: Ada hubungan antara estimasi kapasitas cranium dengan prestasi akademik pada mahasiswa.

Kata kunci: estimasi kapasitas cranium, prestasi akademik, mahasiswa

\section{ABSTRACT}

Background: Many people believe that the greater the size of a person's brain, the higher the level of intelligence. The growth of the human brain goes along with the growth of cranium. One of the parameters that describe the intelligence of a university student is academic achievement. This study purpose to determine the correlation between estimation of cranial capacity with academic achievement of students.

Method: This study was an analytic observational study with a cross sectional approach that use total sampling were students of the fift semester on 2015 of medical faculty at Muhammadiyah Semarang University ( $n=66)$. The estimation of cranial capacity is independent variable and the academic achievement is dependent variable. The bivariate analytic use Pearson correlation.

Results: The mean of estimated cranium capacity was 1570,40 cc and The mean of academic achievement was 2,80. Spearman correlation showed significance value $(p=0.031)$ that there was a correlation between estimation of cranial capacity with academic achievement.

Conclusion: There is a correlation between estimation of cranial capacity with academic achievement in university students.

Keywords: estimation of cranial capacity, academic achievement, university students 


\section{PENDAHULUAN}

Banyak orang percaya bahwa semakin besar ukuran otak seseorang maka semakin tinggi pula tingkat kecerdasannya. Kepercayaan tersebut didasari oleh pernyataan Frederick Tiedmann, ahli anatomi dan fisiologi dari Jerman yang menyatakan: "Tidak diragukan lagi bahwa terdapat hubungan yang sangat dekat antara ukuran pasti dari otak dan inteligensi dan fungsi dari pikiran". ${ }^{1}$

Inteligensi merupakan kemampuan seseorang untuk memperoleh pengetahuan halhal baru, mengimplementasikan pengetahuan, dan berfikir abstrak. ${ }^{2}$ Inteligensi dipengaruhi oleh faktor internal seperti psikologis dan keadaan fisik maupun faktor eksternal seperti lingkungan. ${ }^{3}$

Prestasi akademik merupakan salah satu parameter yang dapat menjabarkan inteligensi seorang mahasiswa. Prestasi akademik adalah hasil usaha kegiatan belajar berupa penilaian yang dinyatakan dalam bentuk simbol, angka, huruf maupun kalimat yang menunjukkan pencapaian dalam periode tertentu. ${ }^{4}$

Inteligensi memiliki korelasi moderat dengan ukuran otak manusia. Pertumbuhan otak manusia berjalan seiring dengan pertumbuhan cranium. Cranium merupakan bagian dari tengkorak yang melindungi otak. ${ }^{5}$ Salah satu indikator untuk menilai pertumbuhan cranium yaitu menggunakan estimasi kapasitas cranium. ${ }^{5}$ Kapasitas cranium adalah ukuran bagian dalam cranium (volume interior). Mitasari (2015) melaporkan bahwa ada korelasi estimasi kapasitas cranium dengan memori jangka pendek siswa SMP.

Mahasiswa adalah pelajar di tingkat perguruan tinggi, baik negeri maupun swasta atau lembaga lain yang setara. ${ }^{6}$ Pada laki-laki, volume intrakranial mencapai puncak pada usia antara 19 sampai 21 tahun. Sedangkan pada perempuan yaitu pada usia antara 16 sampai 18 tahun. $^{7}$

\section{METODE}

Penelitian ini menggunakan metode observasional analitik dengan pendekatan cross sectional. Penelitian dilakukan pada di FK Unimus pada bulan Desember 2018. Populasi penelitian meliputi mahasiswa FK Unimus semester lima. Pengambilan sampel menggunakan teknik total sampling yaitu seluruh mahasiswa semester lima yang memenuhi kriteria inklusi dan eksklusi.

Kriteria inklusi dalam penelitian ini meliputi laki-laki berusia $\geq 19$ tahun atau perempuan berusia $\geq 16$ tahun, mengikuti seluruh rangkaian ujian Computer Based Test (CBT), praktikum, dan Objective Structured Clinical Examination (OSCE) serta bersedia mengisi dan menandatangani informed consent. Sementara, kriteria eksklusi dari meliputi mengalami gangguan mental, riwayat trauma kepala, hidrocephalus, epilepsi, penyakit jantung, dan/atau kejang, melakukan penyalahgunaan alkohol serta sedang mengkonsumsi obat-obatan yang dapat mempengaruhi Sistem Saraf Pusat (SSP).

Penelitian melakukan pengukuran estimasi kapasitas cranium sebagai variabel bebas dan mengambil indeks prestasi kumulatif terhadap 66 mahasiswa semester lima. Estimasi kapasitas cranium diperoleh melalui pengukuran lingkar kepala menggunakan pita ukur. Hasil yang diperoleh dihitung menggunakan rumus: 5,43 $\mathrm{x} \mathrm{L}-1346$ cc. $^{8}$

Data dianalisis dengan uji normalitas Kolmogorov-Smirnov atau uji korelasi Spearman apabila data memiliki distribusi tidak normal.

\section{HASIL}

Dari pengukuran estimasi kapasitas cranium dan indeks prestasi kumulatif semester lima didapatkan hasil seperti pada Tabel 1.

Tabel 1 menunjukkan hasil pengukuran estimasi kapasitas cranium dan indeks prestasi kumulatif semester empat dari subjek penelitian. 
Tabel 1. Hasil Pengukuran

\begin{tabular}{lll}
\hline Variabel & $\begin{array}{l}\text { Estimasi } \\
\text { Kapasitas } \\
\text { Cranium (EKC) }\end{array}$ & IPK \\
\hline $\mathrm{N}$ & 66 & 66 \\
Mean & 1570,4036 & 2,8009 \\
+ SD & 92,45842 & 0,20181 \\
Minimal & 1381,67 & 2,25 \\
Maksimal & 1817,88 & 3,17 \\
\hline
\end{tabular}

Dari 66 subjek penelitian, didapati nilai terendah dari estimasi kapasitas cranium adalah $1381,67 \mathrm{cc}$ dan nilai tertingginya adalah $1817,88 \mathrm{cc}$. Dari perhitungan data didapatkan nilai mean dari estimasi kapasitas cranium adalah $1570,40 \mathrm{cc}$ sedangkan nilai mediannya $1555,43 \mathrm{cc}$. Sementara, nilai simpangan baku dari estimasi kapasitas cranium adalah 92,46. Nilai ini menunjukkan variasi sebaran data. Semakin mendekati 0 nilai suatu simpangan baku, artinya sebaran data dalam subjek semakin mirip nilainya.
Nilai terendah dari indeks prestasi kumulatif semester lima pada subjek penelitian adalah 2,25 dan nilai tertinggi adalah 3,17. Perhitungan data didapatkan nilai mean adalah 2,80 dan nilai mediannya 2,83. Simpangan baku dari variabel ini adalah 0,20.

Hasil dari perhitungan data di atas kemudian diolah dan dianalisis dengan $\mathrm{Uji}$ Normalitas Kolmogorov-Smirnov dan diuji Korelasi yang sesuai.

Tabel 2. Hasil Uji Normalitas

\begin{tabular}{ccc}
\hline & $\mathrm{N}$ & $\mathrm{p}$ \\
\hline EKC & 66 & 0,799 \\
IPK & 66 & 0,030 \\
\hline
\end{tabular}

Tabel 2 menunjukkan hasil uji normalitas data dari kedua variabel. Pada uji KolmogorvSmirnov didapatkan nilai $\mathrm{p}=0,799$ untuk estimasi kapasitas cranium dan 0,030 untuk variabel prestasi akademik. Dari hasil tersebut, didapatkan variabel estimasi kapasitas cranium nilai $p>0,05$ menunjukkan bahwa data memiliki distribusi normal, sedangkan nilai $\mathrm{p}$ $<0,05$ untuk variabel prestasi akademik menunjukkan distribusi data tidak normal.

Dari uji normalitas di atas, disimpulkan bahwa persebaran data memiliki distribusi tidak normal, sehingga menggunakan uji korelasi Spearman.
Tabel 3 menunjukkan estimasi kapasitas cranium dan prestasi akademik ada hubungan positif lemah dengan nilai kekuatan hubungan 0,265 sehingga semakin besar estimasi kapasitas cranium semakin tinggi prestasi akademiknya. Nilai $\mathrm{p}=0,031$ menunjukkan ada korelasi estimasi kapasitas cranium dengan prestasi akademik. Dengan kata lain, ada korelasi lemah estimasi kapasitas cranium dengan prestasi akademik pada mahasiswa. 
Tabel 3. Hasil Uji Korelasi Spearman

\begin{tabular}{cccc}
\hline & Nilai & EKC & IPK \\
\hline & $\mathrm{r}$ & 1 & 0,265 \\
EKC & $\mathrm{p}$ & & 0,031 \\
& $\mathrm{~N}$ & 66 & 66 \\
& $\mathrm{r}$ & 0,265 & 1 \\
IPK & $\mathrm{p}$ & 0,031 & \\
& $\mathrm{~N}$ & 66 & 66 \\
\hline
\end{tabular}

\section{PEMBAHASAN}

Hasil penelitian ini sesuai dengan beberapa hasil penelitian yang menyatakan bahwa ukuran estimasi kapasitas cranium berkorelasi dengan prestasi akademik. Kapasitas cranium mempunyai korelasi kuat dengan volume otak, dan volume otak mempunyai korelasi dengan kecerdasan, dan kecerdasan seseorang ikut menentukan intelegensi, yang pada akhirnya berhubungan dengan prestasi akademik. ${ }^{9,10}$ Mitasari (2015) melaporkan bahwa ada korelasi estimasi kapasitas cranium dengan memori jangka pendek siswa SMP.

Penelitian terdahulu menyatakan bahwa volume otak mempunyai korelasi dengan kecerdasan. Hasil ini didapatkan dari penelitian dengan subjek penelitian berasal dari beberapa negara. Subjek penelitian diukur kapasitas cranium dan intelegensinya. Dari hasil analisis data didapatkan bahwa orang Cina memiliki rata-rata kapasitas cranium paling besar dibandingkan dengan subjek dari beberapa negara lain, dan pada saat yang sama didapatkan bahwa orang Cina juga memiliki rata-rata IQ terbesar dibandingkan dengan subjek dari beberapa negara lain tersebut. ${ }^{11}$

\section{KESIMPULAN DAN SARAN}

\section{Kesimpulan}

Dalam penelitian ini, dapat disimpulkan bahwa ada hubungan antara estimasi kapasitas cranium dengan prestasi akademik pada mahasiswa.

\section{Saran}

Diperlukan penelitian lebih lanjut mengenai estimasi kapasitas cranium dengan metode lain.

\section{DAFTAR PUSTAKA}

1. Reynolds CS, Jaworski HM, Cmiech HA, Leedale GF. On the annual cycle of the blue-green alga microcystis aeruginosa kütz. emend. Elenkin. Philosophical Transactions of the Royal Society of London. Series B, Biological Sciences. 1981;293(1068):420-488.

2. Mackintosh NJ. IQ and human intelligence. 2nd ed. Oxford: Oxford University Press. 2011.

3. Bearce K. Intelligence quotient. Personal Communication 2009. Available From: URL Hiperlink: https:// www.mccc.edu/ jenningh/Courses/docu ments/Handout-Intelligence_000.pdf

4. Walgito B. Pengantar psikologi umum. Yogyakarta: Andi Offset 2003.

5. Shiel WC, Stoppler MC, editors. Webster's new world medical dictionary. New Jersey: Wiley Publishing. 2008.

6. Sgouros S. Skull vault growth in craniosynostosis Child's Nervous System 2005;21(10):861-870.

7. Siswoyo D. Ilmu pendidikan. Yogyakarta: UNY Press. 2007.

8. Dekaban AS, Sadowsky D. Changes in brain weight during the span of human life: relation of brain weight to body height and body weight. Ann. Neurol.1978 ;4(4): 345-356. 
9. Jorgensen JB, Quaade F. External cranial volume as an estimate of cranial capacity. American Journal of Biological Anthropology. 1956;14(4):661-664.

10. Sahin B, Acer N, Sonmez OF, emirzeoglu $\mathrm{M}$, Basaloglu $\mathrm{H}$, Uzun A, et al. Comparison of four methods for the estimation of intracranial volume: A gold standard study. Clinical Anatomy. 2007;20(7):766-773.

11. Witelson SF, Beresh H, Kigar DL. Intelligence and brain size in 100 postmortem brains: Sex, lateralization and age factors. Brain. 2006;129(2):386-398. doi: 10.1093/brain/awh696.

12. Wolff $H$. Eye size, brain size, and intelligence. American Renaissance. 2011. Available From: URL Hiperlink: http://www.amren.com/commentary/201 1/09/eye-size-brain-size-and-intelligence. 